This item was submitted to Loughborough's Research Repository by the author.

Items in Figshare are protected by copyright, with all rights reserved, unless otherwise indicated.

\title{
Corporate responsibility practices in engineering consultancies
}

PLEASE CITE THE PUBLISHED VERSION

http://dx.doi.org/10.1080/15623599.2011.10773166

\section{PUBLISHER}

(c) The Chinese Research Institute of Construction Management (now published by Taylor and Francis)

\section{VERSION}

AM (Accepted Manuscript)

\section{LICENCE}

CC BY-NC-ND 4.0

\section{REPOSITORY RECORD}

Willetts, Richard, Jim Burdon, Jacqueline Glass, and Matthew W. Frost. 2019. "Corporate Responsibility Practices in Engineering Consultancies”. figshare. https://hdl.handle.net/2134/11652. 
This item was submitted to Loughborough's Institutional Repository (https://dspace.lboro.ac.uk/) by the author and is made available under the following Creative Commons Licence conditions.

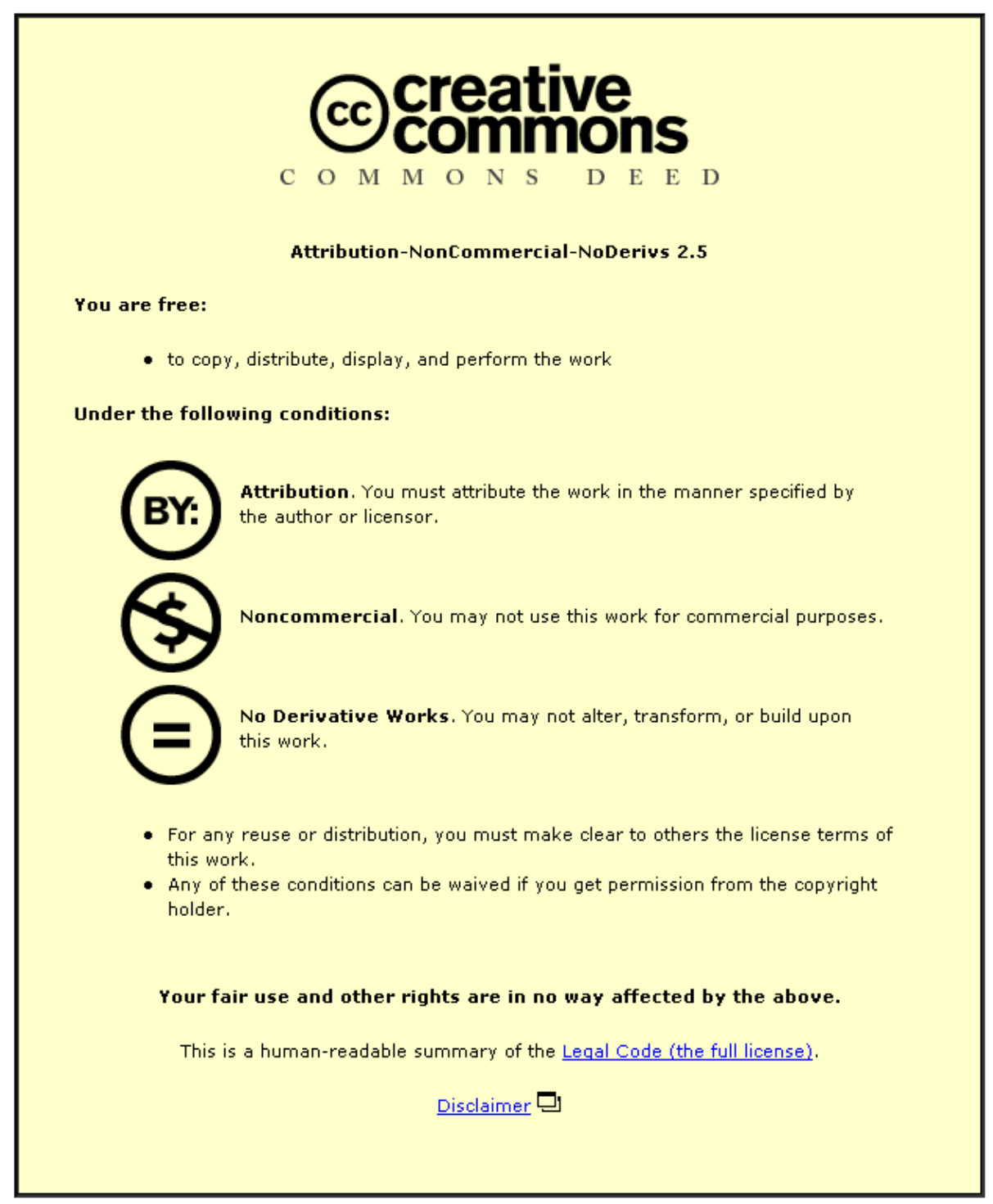

For the full text of this licence, please go to: http://creativecommons.org/licenses/by-nc-nd/2.5/ 


\title{
CORPORATE RESPONSIBILITY PRACTICES IN
}

\section{ENGINEERING CONSULTANCIES}

Richard Willetts MEng Research Engineer Jacobs Engineering ${ }^{1}$ Loughborough University ${ }^{2}$

Jim Burdon BEng Technical Director Jacobs Engineering ${ }^{1}$

Jacqui Glass BA(Hons) DipArch, DipBRS, CertHE, PhD Senior Lecturer Loughborough University ${ }^{2}$

Matthew Frost BEng (Hons), DIS, PhD, PgCHE, Lecturer Loughborough University ${ }^{2}$

1 Jacobs Engineering, 10 Nottingham Road, Derby, DE1 3QT

2 Department of Civil and Building Engineering, Loughborough University, Loughborough, LE11 $3 T U U K$

Lead Author: Richard Willetts e-mail:richard.willetts2@jacobs.com

\begin{abstract}
This paper aims to identify the current level of adoption of some common CR practices in the largest global construction and engineering consultancies drawn predominantly from the UK and USA. The paper begins by outlining the benefits of $\mathrm{CR}$ and its role within modern business before taking a look at the current literature available on $\mathrm{CR}$ applied to the construction industry.
\end{abstract}

Using content analysis of annual reports, corporate websites and other corporate communications, a summary of current practices has been identified and compared with recent studies of global trends and best practices. It is clear that the organisations considered are aware of the CR agenda with widespread adoption, but they have some way to go before catching up with the global leaders; they need to expand the range of issues considered, be 
more transparent and accountable in their reporting and find new ways to improve their CR performance.

Key words

Sustainability, CSR, Strategy, Consulting, Reporting 


\section{INTRODUCTION}

The adoption of corporate sustainability and corporate social responsibility reporting has received growing acceptance in the business world. Recent surveys indicate that the number of companies undertaking such reporting has grown from $50 \%$ five years ago, to close to $80 \%$ in the 250 largest global companies (KPMG, 2008). It has been shown however that the majority of companies reporting are multinational corporations (Gjolberg, 2009), which is believed to be due to their increased public exposure to varied markets and diverse cultural issues. To date the greatest progress in reporting has come from the extractive and manufacturing industries with a much slower response from the service industries and construction sector.

Whilst some studies have been undertaken to look at current practices in the construction industry these mainly consider specific elements such as ethics or welfare, or major on the impacts of the construction process such as waste or materials. Little attention has been paid to the practices of consultants and this research examines the role of corporate responsibility (as the communication of commitment to corporate sustainability) and the current level of implementation in consulting engineering. The research is based on information in the public domain, predominantly using company annual reports and websites.

\section{CORPORATE SUSTAINABILITY AND CORPORATE SOCIAL}

\section{RESPONSIBILITY}

Sustainability has increased in profile in management literature in recent years (Porter and Kramer, 2006; Koltler and Lee, 2005; Orlitzky et al, 2003) with an increasing focus from the 
corporate world. Corporations are increasingly being held responsible for the impacts they make in the societies in which they operate (Hartman et al, 2007), but they also recognize the benefits that corporate responsibility can bring. Frynas (2009) cites a McKinsey survey (Bielak et al, 2007) showing that 95\% of CEO's believe that society has greater sustainability expectations on them than five years ago and over half believe these expectations will be significantly greater in another five years, particularly regarding public responsibilities.

At present the terms corporate responsibility (CR), corporate social responsibility (CSR) and corporate sustainability (CS) are all used in published literature; their use is well defined in academic literature, whereas management literature tends to use the terms interchangeably. Montiel (2008) suggests that while they may come from different origins (with articles on CSR being published since the 1970's and CS not being published until the 1990's), they are merging topics with significant areas of overlap, especially within their implementation in the corporate world. For the purpose of this paper, they shall be used interchangeably.

While CSR may have grown out of dialogue over the role of the company versus the government in issues such as employee welfare or Health and Safety, before moving on to consider specific environmental issues. CSR has now moved on from simple philanthropic giving to being the basis for responsible decision making throughout an organisation's structure and alignment with its business strategy (Zollo, 2008). Szekely and Knirsch (2005) believe that pursuing sustainability for business involves the implementation of more ethical business practices, attending to the needs of stakeholders and sustaining and expanding economic growth, whilst also minimising impacts on the environments and societies they operate in.

Although it is easy to dismiss these concerns as not aligned with the business's role to increase shareholder value (Corporate Watch, 2006) there has been a clear shift towards 
stakeholder value theory (Freeman, 1984; Reich, 1998; Brown and Fraser, 2006) whereby organisations listen and adapt their businesses to the needs of internal, external and institutional stakeholders. This helps companies identify a number of drivers for the adoption of more sustainable practices. For example, Bansal and Roth (2000) considered motives for improving corporate environmental performance to be; increased legislation, stakeholder pressures, economic opportunities and ethical motives (citing work by Dillon \& Fischer, 1992; Lampe, Ellis, \& Drummond, 1991; Lawrence \& Morell, 1995; Vredenburg \& Westley, 1993; Winn, 1995).

Significant research has been undertaken to establish the financial benefit of corporate responsibility activities to organisations, with some studies (such as Mercer, 2009; BITC 2009; Peloza and Yachnin, 2008) showing that firms which embrace CR outperform those who have stuck to the more traditional mind-set of "the role of business is business". Other studies have not been so successful in establishing this link, although a few have found there to be a negative correlation. For instance, in a review of financial performance, Perrini et al (2009) found research measuring social performance with financial performance to be inconsistent, they acknowledged the relationship complex and nuanced and therefore difficult to make a case either way. However, Perrini at al (2009) did identify a number of other areas that $\mathrm{CR}$ added value to the business in line with the drivers mentioned above. The study found a strong link between reduced environmental impacts and enhanced financial performance (arising from improved efficiencies and reduced liabilities) showing that CR has a potentially profitable role to play. They also identified a strong case within literature that increased organisational concern for social and ethical issues, when transformed into policies and programs, leads to improved employee satisfaction, well-being and behaviour (e.g. Davis and Rothstein, 2006; Prottas, 2008) as well as increased employee commitment (espoused by 
Valentine and Barnett, 2003), motivation (Grant, 2007) and employer attractiveness for new candidates (Greening and Turban, 2000), which all contributed to increased organisational benefits as identified by Paine (2003), such as lower staff turnover, higher productivity and greater appeal.

Enhanced trust and client loyalty have also been identified (e.g. Smith, 2003; Luo and Bhattacharya, 2006) as benefits of the adoption of CR, due to improved dialogue with clients and consumers which creates higher satisfaction levels (Bhattacharya and Sen, 2003) through an enhanced reputation (Castaldo et al 2009; Hammond and Slocum, 1996), leading to a competitive advantage (Freeman et al, 2007; Menon and Menon, 1997; Podnar and Golob, 2007).

The final area that Perrini et al (2009) identify as benefiting is an enhanced relationship with the financial community (because firms engaging in CSR are perceived to have lower risk due to enhanced disclosure and reporting of potential liabilities from environmental and social issues along with the belief that they are better engaged in dialogue to satisfy their stakeholders). Pleon (2005) identified the financial community as the stakeholder that most greatly appreciated the benefits of reporting on CR issues, and Arnold (2008) discusses how reporting of non-financial issues has grown in acceptance in recent years. Yet Amaeshi (2010) notes that the current level of reporting is still not sufficiently detailed to persuade investors of its importance as there is a lack of clarity in ownership of environmental, social and governance issues (EABIS, 2009).

Reporting is the main method of dialogue adopted by most organisations to discuss nonfinancial impacts and as such has come under a great deal of scrutiny. It has also lead to the development of a number of voluntary standards, for reporting such as the GRI $\begin{array}{lllll}\text { (http://www.globalreporting.org), } & \text { SA } 8000 \quad \text { (http://www.sa-intl.org/), } & \text { ISO26000 }\end{array}$ 
(tinyurl.com/29csnds) and AA1000 (http://www.accountability.org/) In many cases, companies need to implement change to be able to report against these standards and so a body of literature has developed around the different phases that businesses go through on their journey. Indeed, a variety of business models and organisational change models now exist (e.g. Dunphy et al, 2003; Doppelt, 2010; Epstein, 2008; Maon et al, 2010) to show the process for integrating corporate sustainability. These complement a growing number of associations and initiatives that have been developed to support the integration of CSR into day to day business (EU, UN, OECD, GRI, WBCSD). There is however a disconnect between some firms' communicated intentions and their actions (Jackson 2010), which presents a difficulty for those interpreting publicly available information such as corporate sustainability and CR reports. If we consider the specific case of CR reporting in engineering consultants we can see that these discussions points remain pertinent.

\section{Corporate responsibility in construction}

A large body of work has been produced looking at the role of sustainability in the construction sector, but to date the majority of this focuses on the impact of buildings and materials (Willetts et al, 2010). At present there is less emphasis on the efforts of individual businesses to address $\mathrm{CR}$, despite the industry being classed as having a high impact across a broad range of issues such as emissions, waste, energy and water usage as well as its scale and size of labour force. This important gap in research was first recognised by Wilkinson et al (2004), but a much smaller body of work exists on the role of CR in the construction industry (e.g. Jones et al, 2010; Myers, 2005; Brown et al, 2009; Murray and Dainty, 2009 and Petrovic-Lazarevic, 2004), and very little attention has been paid to consultants. 
A review of CR reporting in the UK construction sector (Brown et al, 2009) identified the most commonly reported issues to be health and safety, energy and resources, carbon, supply chains and community, while Myers (2005) found that the industry was generally poorly engaged with the CR agenda despite its environmental and social impacts. GRI (2008) also undertook a study of sustainability reporting in the global construction sector and again found the reporting in the sector was less developed than many other sectors with those leading being located in Japan, Australia and Europe. Their reports showed an emphasis on climate change issues and carbon, but a poor understanding of economic impacts. This suggests that there is scope for a more detailed consideration of $\mathrm{CR}$ in the construction sector and more particularly, consultants.

\section{COMPARISON OF CONSULTANTS CR PERFORMANCE}

Recognising that there is gap in the research on how the consultancy sector is interacting with the CR agenda, this study considers how the largest global consultants are performing on a number of key topics compared to the leading companies in the world from other sectors and also with recognised best $\mathrm{CR}$ practices. To a certain extent, the pace of change in the field is so fast-moving that it is practice-driven rather than academically-driven, so best practices are often drawn from practice-based guidance that has yet to be confirmed in the academic literature, despite being widely adopted and implemented.

\section{Methodology}

Content analysis was selected as an appropriate approach to carry out a comparison of CR; it has been used previously to review corporate responsibility issues in construction, e.g. Myers (2005); Jones et al (2010). Myers (2005) claims it is suitable because it is "...objective, 
consistent and repeatable..." and has some history in its use in both the construction sector (Drexer and Larson, 2000; Yu et al, 2006), the sustainability arena (UNEP 2000; 2002; WWF, 2004; and Sustainability et al, 2004) and corporate responsibility (Unerman, 1999; Milne and Adler 1999).

This research study reviewed various sources of secondary data to provide a better understanding of current practices. A matrix was constructed of companies and pertinent themes from the literature and used to collect and analyse the data. In this instance, the use of data counts of specific words or phrases was not considered insightful.

Data was collected from annual reports, CR reports and company websites. Although there is an argument in the literature for using annual reports (Adams and Harte, 1998), the other documents were chosen to give a more rounded picture of each company's CR practices, recognising that solely considering corporate reports might not give the complete picture, as acknowledged by Roberts (1991). Using an expanded selection of documents was also possible as the analysis was only looking at the current year's reporting and not measuring progress over time, so there was not a risk of being overwhelmed by material.

Comparisons were made with trends from two recent studies, Craib and PriceWaterhouseCooper (2009), hereafter referred to as Craib and PWC (2009), and KPMG (2008). Craib and PWC (2009) looked at over 1,115 firms from the world's largest indices to establish best practices in CSR before finding benchmarks for implementation using 100 companies, split evenly between US, Canada, Europe/ Japan/ Australia, and the rest of the world. KPMG (2008) undertook a survey of reporting trends of 2,100 companies, including the G250, representing the largest 250 global companies as well as the largest 100 companies from 22 countries. 
The firms that were chosen for this research were based on the ENR (Engineering News Record) 2009 Top 500 design firms, NCE (New Civil Engineer) 2009 Consultants File and ENR 2009 Top Global design firms. This allows the biggest global, US based and UK based firms to be selected for analysis providing a global overview as well as comparison between US and European firms. There was some overlap on these lists, so a total of twenty firms were selected. The companies reviewed were:

- $\mathrm{AMEC}$

- Arup

- Atkins

- Bechtel

- $\mathrm{CH} 2 \mathrm{MHILL}$

- Flour

- Fugro

- Jacobs

- $\mathrm{KBR}$

- Mace

- Mott MacDonald Group

- Mouchel

- Parsons Brinckerhoff 
- $\quad$ RPS Group

- Shaw Group

- SNC-Lavalin International

- Tetra Tech Inc.

- URS Corp.

- Worley Parsons

- WSP Group

The companies in this sample represent the USA (9), UK (8), Netherlands (1), Canada (1) and Australia (1), with multiple companies claiming offices in over 40 countries and some companies claiming to have projects in over 140 countries. Staff sizes range from $2.800-$ 50,000 with over 450,000 directly employed across the 20 companies. Revenues range from $\$ 0.45 \mathrm{bn}$ to $\$ 30 \mathrm{bn}$, with a total sample revenue of $\$ 550 \mathrm{bn}$. These figures highlight the scale of the construction consultancy sector as well as their scale and reach internationally.

\section{RESULTS}

The results of the analysis are presented here under two key themes that were found within the CR documents: communication and reporting, and management and organisational performance.

\section{Communication and reporting}

Company websites 
Of the 20 companies selected it was found that 19 companies referenced the concepts of sustainability and/or social responsibility on their websites in some format. Ten provided a single web page, seven providing a section with multiple pages with two providing standalone websites to explore their CR implementation and $40 \%$ placing a link to related issues on the front page of their website. This correlates with Craib and PWC (2009) who found that an average of $75 \%$ of corporate websites contained CR information, but only $40 \%$ provided a link on the front page. Environment, employees, health and safety and community were the most frequently covered issues, with comparatively little focus on management systems or supply chains.

Websites and internet pages have been used as one of the main methods of reporting disclosures. Esrock and Leichty, (1998) and Neu et al (1998) found that communication was nearly always one-directional with an information push from the organisation with little ability for dialogue, a tendency to focus on positive impacts and good news stories, and an absence of reporting on negative impacts. These findings are in line with the examples considered in this study with a few sites providing a link to an email address to raise CR queries but none with mechanisms in place for dialogue or discussion. This interaction is now becoming best practice in CR reporting; web 2.0 and social media applications are now recognised as a potential way to increase awareness (Fieseler et al, 2010)

\section{$\underline{\text { Report format }}$}

Nine of the organisations (45\%) published stand-alone reports with six being referred to as sustainability reports, one as a corporate responsibility report and one as a sustainability and corporate responsibility report, with lengths varying from 27 to 134 pages. In comparison $79 \%$ of the G250 published reports in 2008 , up $30 \%$ in the previous three years; where it was found that the UK and Japan were leaders in reporting (KPMG, 2008). Makower (2009) 
noted that in the S\&P500, $57 \%$ of reports were titled corporate responsibility and $23 \%$ sustainability which contrasts with the adoption of terminology in the organisations studied here.

Of the remaining 11 companies, seven (35\%) integrated their reporting into annual reports; this is in contrast to the $3 \%$ of G250 firms who used integrated reporting (KPMG 2008). Discussions ranged from 1-16 pages, noticeably shorter than those who published stand-alone reports. The companies that produced separate sustainability reports also mentioned their sustainability practice in their annual financial reports but far more briefly. Of the remaining four companies, there was no discussion of performance on CR; these were all US-based companies and highlights an important difference of adoption compared to the UK based firms.

\section{$\underline{\text { Reporting standards and guidelines }}$}

Of the 20 companies, $25 \%$ (4 US and 1 UK) followed the reporting guidelines of the Global Reporting Initiative (GRI) compared to $77 \%$ of the G250 (KPMG, 2008), with three not rating themselves, one rating themselves a $\mathrm{B}$ and one a $\mathrm{C}$. Only one company provided a third party verification of the reporting. The GRI provides a framework for companies to report, with a selection of issues that companies might be responsible for and a consistent method of reporting, allowing easier comparison between performance of companies as well as awarding ratings for levels of compliance with the framework.

Of the other frameworks that could be used to implement CR, AA1000 was not used by any companies compared to an uptake of $10 \%$ among the G250; SA8000 was used by one UK company (very much in line with the 5\% use within the G250) and two companies (1 USA and $1 \mathrm{UK}$ ) subscribed to the UN Global Compact, compared to $40 \%$ in the G250 (KPMG, 
2008). No other guidelines were utilised. The UN Global Compact has 7,300 members and provides a strategic policy for business to report alignment and performance annually on ten principles covering human rights, environment and anti-corruption. Only one report was third party verified (using AAS1000AS), while two acknowledged this to be a future plan. This contrasts with Craib and PWCs' (2009) findings that 44\% of G250 reports provided assurance statements in which $47 \%$ were criticised for bad reporting by the third party, with mining, utilities and oil and gas being the three strongest industries on providing third party assurance (KPMG, 2008). However, it is expected that assurance will become a growing trend as companies look to demonstrate that their reports are credible because stakeholders are demanding greater transparency. At the moment assurance is predominantly provided by large accounting and auditing firms using frameworks such as AA1000AS, ISAE3000 and GRI Guidelines (Ackers, 2009).

\section{Management and organisational performance}

\section{Organisational governance}

Six firms had a sustainability policy while nine addressed sustainability in their mission statements or values. The importance of showing commitment to $\mathrm{CR}$ at this level has been highlighted by Mirvis et al (2010), but previous work showed only $23 \%$ of employees were found to believe that company mission statements guided their actions (BetterWorkplaceNow, 2000). Nevertheless high level commitment is still seen as one of the best ways to drive the message both internally and externally that an organisation is not just looking for good PR, but seeking to establish a long term business plan.

Seven companies had responsibility for CR at board level while six had sustainability committees. This is important; EABIS (2007) found that influence at board level, top 
management support, committee influence and the frequency of presentation of CR issues to the board were strongly linked to better performance on CR issues. Spitzeck (2010) also discusses the important role that committees and board champions have to play in the success of good CR.

Five of the companies discussed how they had put in place knowledge management systems which they believed were helping them to deliver sustainable solutions, while six (all UK) discussed the development of leadership training schemes in sustainability for staff. Four (1 USA, 3 UK) mentioned integrating sustainability issues into staff inductions.

\section{Performance and target-setting}

One company assessed was listed on the Dow Jones Sustainability Index, with one due to be listed, while three companies were listed under FTSE4 Good. These specialist indexes look to highlight the companies that are leading performers in corporate responsibility and ensure that a number of criteria are met to maintain inclusion. Presence on the indices is seen to highlight good communication between the company and financial markets.

Eight (2 USA, 6 UK) had measurable targets in their reports mainly linked to carbon, while only four $(25 \%)$ had targets across environmental, social and economic issues, provided an overview on a single page. By comparison Craib and PWC (2009) found that 59\% of analysed reports provided a summary of objectives on a dedicated page, with $46 \%$ reporting progress and 52\% providing targets. This reflects the findings of Satija (2009) who found that the reports were most likely to present aspirations without showing a strong connection to action; the lack of benchmarking and verification also makes it hard to confirm that progress is genuine. Jackson (2010) stated that incorporating CR Key Performance Indicators (KPI's) was one of the ways to ensure managers developed a better understanding of the relevance of 
CR to the company and day to day work, while Ferguson (2009) provided insight into how implementing robust targets and measures improves $\mathrm{CR}$ performance and competitive advantage.

Carbon was discussed by 14 firms with 11 companies ( 2 USA, 3 international and 6 UK) reporting under the Carbon Disclosure Project (CDP), but only eight of the 20 discussed wishing to reduce $\mathrm{CO}_{2}$ and only four (25\%) published reduction targets. This is compared to findings of Craib and PWC (2009) who found 87\% of companies reported greenhouse gas emissions, with $68 \%$ of European, Australian and Japanese companies publishing targets.

\section{$\underline{\text { Social accountability }}$}

Ten of the companies had clearly stated volunteer programmes in place, split evenly across nationalities. Only three had matched staff giving schemes and eight reported clearly on their charitable donations, ranging in value from $\$ 101 \mathrm{k}-\$ 7 \mathrm{~m}$. The sums donated by US-based firms were of the order of ten times the size of those given by the UK firms. Philanthropy is often not considered an important part of CR in Europe as it is not part of a business's operations (Frynas, 2009), but can be an important way for companies to integrate, especially if they develop relationships with organisations who can benefit from the skills the company has or is located in the community in which the organisation operates.

Five companies (2 USA/3 UK) have implemented wellbeing policies for staff, while eight had zero harm policies. Health and safety was a strong theme in the majority of the reports, which is not surprising given the nature of the industry and focus that has been given to improving the safety of construction work. This was the most frequently reported data that included actual figures, showing that firms were comfortable to discuss the issue and had systems in place to monitor performance. 


\section{$\underline{\text { Stakeholder identification and engagement }}$}

While nearly all firms mentioned stakeholders, (the most common being client, employee, communities and shareholders), only 10\% mapped them and just one provided a clear outline of the dialogue employed to address each stakeholder and their materiality (the process of identifying the issues over which the firm has influence). This does not align with Craibs and PWC's (2009) findings that $48 \%$ of European, Australian and Japanese firms and $24 \%$ of US firms explain materiality, with $76 \%$ describing the specific engagement methods used and $33 \%$ outlining the findings from the dialogue. None of the consultants considered produced a materiality index such as those highlighted by AccountAbility (2006). These are considered to be best practice and illustrate the importance of issues raised from dialogue for both the stakeholders and the organisation, showing areas most in need of attention.

Risk was covered by $25 \%$ of companies, albeit very briefly (generic statements on recognising risk) by all but one, this compares with $66 \%$ who reported in Craibs and PWC (2009) study. Interestingly, the exception was the only company to discuss it had engaged with the SRI (Socially Responsible Investment) community. This community seeks to invest in ways to maximise economic and social outcomes and represents $7 \%$ (by value $\$ 7$ trillion) of the global financial market and growing (Bitman and Fargo, 2009). The company concerned was asked to be more detailed in their disclosure of risk in their CR report; they took this on board and then provided the most comprehensive disclosure of all the reports, showing the positive impact of two-way dialogue.

The voluntary nature of reporting means negative aspects are often not reported; only six reports commented on negative impacts such as fraud, environmental incidents and health and safety incidents. These were all extremely brief, typically a paragraph focussing on a specific incident. Transparency is one of the most discussed topics in CR and, for reports to 
be considered more than PR exercises, it is essential that companies highlight not only the good, but also areas of concern and in need of improvement. This will allow readers to get a more rounded view of the company's performance, similar to that achieved regarding financial reporting and liabilities.

\section{DISCUSSION AND RECOMMENDATIONS}

Having considered the reports in detail and with reference to salient literature, we now develop a series of recommendations to help consulting engineering firms engage with CR.

At present reporting is predominantly in PDF and paper format with only three companies providing online customisation, which is being seen as the way forward in best practice. This allows reporting online to be formatted and put together in a way that is suitable for the reader because at present the intended audience is not always clear. Inclusion of a single page 'dash board' on performance would also be beneficial, as well as use of alternative media and inclusion for greater dialogue with stakeholders. Companies should recognise when working across territories that readers in India might have very different interests from those in America or Latin America, while investors will require different information from clients or local communities. Therefore it is important that the information is comprehensive and relevant, but provided in a format that allows it to be optimised by the reader.

While companies are reporting on carbon, there is no consensus on the reported indicators, making it hard to perform comparisons. It being commonly normalised, variously, by employees, turnover, or area. Companies should provide total amounts as well as publish year on year progress allowing the reader to better understand overall performance, targets and if they are being met. Companies would do well to look to reporting on waste and water in a 
similar manner to current disclosures on carbon and energy as this would provide a more holistic view of the company's environmental impacts.

A vast amount has been published on the importance of dialogue and good engagement, and while most of the companies claim to be engaging at present they only name a small core of stakeholders. This lacks detail on engagement methods and feedback, possibly hindering the full benefit of the engagement. It is also unclear what processes are being used to establish materiality and in which areas. Consultants could learn from the leading companies in other sectors, such as mining, oil and gas, chemical and pharmaceutical who, by the nature of their industries and media attention, have been early adopters of stakeholder dialogue techniques.

They could also look to expand their dialogue with NGO's. While many look to engage through philanthropy, only a couple are building relationships with NGO's and using these to receive feedback and leverage competitive advantage based on CR through reduced risk and enhanced reputation. Lack of alignment, via charity and volunteer actions with the direction of the business, means that consequently they are not looking to help local communities or charities that could utilise the firm's knowledge. It is also important that companies don't claim individual staff actions that sit outside of the company's policies as part of their CR progress; this can misrepresent their genuine contribution.

Two of the most important themes in good CR and receiving ever greater attention are the role of accountability and transparency. At present the majority of the firms in this study are in the infancy of the journey to improving both of these but there is a long way to go. For CR to make the greatest impact it is essential that firms provide stakeholders with more detailed disclosures relating to the way the organisation is addressing CR issues throughout its operations. To help with this a wide variety of standards and guidance exist, such as those by GRI, Accountability, WBCSD and ISO. Companies should look to adopt these templates to 
ensure a comprehensive range of subjects are covered ensuring the maximum impact of CR implementation and allowing readers to better compare performance on a range of issues between firms. Third party verification will also have a role to play, allowing firms to receive feedback on their programmes and reporting. This provides stakeholders with a degree of certainty that the content is accurate, as well as highlighting weaknesses and helping investors, clients and other stakeholders to make better informed choices.

While a few companies have looked to allocate responsibility for $\mathrm{CR}$ at board level, this should be adopted more widely as it has been shown that the higher the level of support and more frequent the presentation of CR issues to board level members, the more successful the implementation. Consultancies can also look to better integrate CR across the organisation and into public relations, communications, marketing and HR functions within the business. HR in particular can be beneficial for allowing greater development of employee training and awareness, providing incentives and revising reward schemes, linking CR performance with remuneration and empowering employees to engage with all stakeholders.

Along with the voluntary frameworks that have been developed to assist in reporting good $\mathrm{CR}$, a number of academic and practitioner developed phase change models have been developed to show the transition companies go through while adopting CR. Some of these models have been summarised and consolidated by Maon et al (2010), as seen in Table 1.

\section{INSERT TABLE 1}

Recognising these stages, as well as their current positions on a variety of issues set out in the framework they developed, would allow consultancies to benchmark their current position and utilise a phase change model, such as that developed by Maon et al (2008). This 
consolidates existing literature and practice to identify nine steps that will assist an organisation in implementing a CR policy, these being:

1. Raise CSR awareness inside the organisation

2. Assess corporate purpose in its societal context

a. Identify key stakeholders and critical issues

3. Establish a vision and a working definition for CSR

4. Assess current CSR status

a. Benchmark competitors' CSR practices and CSR norms and standards

5. Develop a CSR-integrated strategic plan

6. Implement the CSR integrated strategic plan

7. Communication about CSR commitments and performance

8. Evaluate CSR integrated strategies and communication

9. Institutionalise CSR

This change model provides a robust framework for consultancies to change their current CSR paradigm when supplemented with the work of Bertels et al (2010); which provides an extensive resource of the current tools and change methods that can be utilised to embed sustainability in organisations along with supporting examples or empirical evidence for the impact of each initiative or procedure. They identified 13,756 pieces of literature relevant to embedding sustainability, before narrowing it down to 96 highly relevant sources and allowing them to construct a tool to identify the most suitable methods for fostering 
commitment, clarifying expectations, building momentum for change and instilling capacity for change, identifying methods and resources for each case.

\section{CONCLUSION}

It is clear from the existing literature that $\mathrm{CR}$ will be a major issue for business in the coming years, representing a phase change in business practice as movements such as health and safety, quality management and IT did in previous decades. The benefits to business are wide ranging and diverse, with many companies beginning to see results. It is also clear that construction and engineering projects are often high impact with large demands on resources and communities; CR provides a mindset to help consider and minimise these impacts and if well implemented, leads to increased staff awareness, lower impacts and better alignment with stakeholders in all elements of work, increasing overall company value.

It is clear from the research that CR reporting and implementation in consultants is generally lagging behind other sectors and this has been found to be true in general for the wider construction industry. There is a clear difference between European and US-based firms on the use of integrated reporting, but the American firms appeared to make much larger charitable donations.

Whilst it is obvious from the research that sustainability is now a topic of importance for nearly all the companies in the study the current levels of discussion are remarkably varied. Even in this small sample, this ranges from no acknowledgement, to a company making use of many reporting best practices and leading the way on such reporting in both the USA and Europe. 
At present it is clear that environmental issues remain the most well understood and discussed within these CR reports, with the majority of companies publishing an environmental statement. Social issues that focus on employee welfare and diversity issues are very common; although communities is a commonly discussed term in the reports, at present there seems no clear consensus on what this involves or how to measure or report it. Economic issues appear the least well understood with the least focus and dialogue, perhaps because firms feel this is addressed better in annual reports.

The general CR themes found within company literature were very much in line with those found by Brown et al (2009) and it is interesting that the focus that carbon has obtained perhaps because it is perceived as a current "hot topic" as well as an area for financial saving, with common initiatives reported revolving around energy efficiency measures in offices.

The quality of CR reporting was also called into question with some criticisms around the veracity of some firms' stakeholder engagement statements; there is a clear opportunity for consultants to improve their approach and document it carefully. This research has also reiterated the importance of using robust reporting standards for accuracy and comparability.

Finally some recommendations have been made on how consultants can look to broaden and deepen their current CR practices including many emerging best practices from other sectors and emphasised the importance of transparency and accountability for good CR to be effective.

\section{ACKNOWLEDGMENTS}


The study by the authors into sustainable infrastructure design and delivery receives contributory funding from the EPSRC via the Engineering Doctorate Scheme run from the Centre for Innovative and Collaborative Engineering at Loughborough University. The views expressed in this paper are solely those of the authors and not those of Jacobs Engineering.

\section{Words 5949}

\section{REFERENCES}

AccountAbility. (2006). Guidance note on the principles of materiality, completeness and responsiveness as they relate to the AA1000 assurance standard, Accountability, London, UK.

Ackers, B. (2009). Corporate social responsibility assurance: how do South African publicly listed companies compare? Meditari Accountancy Research 17 (2), 1-17.

Adams, C.A., and Harte, G. (1998). The changing portrayal of the employment of women in British banks' and retail companies' corporate annual reports, Accounting, organisations and Society, 23(8), 781-812.

Amaeshi, K. (2010) Rethinking the link between Corporate Responsibility and Financial Performance: a tale of strange bedfellows?. The Doughty Centre for Corporate Responsibility, Cranfield Univeristy, UK.

Arnold, M, F., (2008). Non-Financial Performance Metrics for Corporate Responsibility Reporting, Doughty Centre for Corporate Responsibility, Cranfield University, United Kingdom.

Bansal, P. and Roth, K. (2000). Why companies go green. A model of ecological responsiveness. Academy of Management Journal, 43(4), 717-736. 
Bielak, D., Bonini, S. and Oppenheim, J., (2007). CEOs on Strategy and Social Issues, Mckinsey and Company.

Bertels, S., Papania, L. and Papania,D,.(2010). Embedding sustainability in organizational culture: A systemic review of a body of knowledge. Network for Business Sustainability, Ontario, Canada.

BetterWorkPlaceNow, (2000). Workplace 2000 Employee Insight Survey: A Report of Key $\begin{array}{lllll}\text { Findings, } & \text { Retrieved } & 01 & \text { January } & 2011\end{array}$ http://www.betterworkplacenow.com/insightsurvey/

Bhattacharya, C. B. and Sen, S. (2003). Consumer-company identification: A framework for understanding consumers' relationships with companies. Journal of Marketing, 67(2), 76-88.

Business in the Community (BITC). (2009). The Value of Responsible Business, Retrieved 24 November 2010 from http://www.bitc.org.uk/resources/publications/the_value_of.html

Brown, J. and Fraser, M. (2006). Approaches and perspectives in social and environmental accounting: an overview of the conceptual landscape. Business Strategy and Environment, $15,103-117$.

Brown, J., Parry, T. and Moon, J. (2009). Corporate responsibility reporting in UK construction. Engineering Sustainability, 162(4), 193-205.

Castaldo, S., Perrini, F., Misani, N. and Tencati, A. (2009). The missing link between corporate social responsibility and consumer trust: The case of Fair Trade products. Journal of Business Ethics, 84(1), 1-15. 
Craib Design \& Communications and PricewaterhouseCoopers (2009) CSR Trends 3

Retrieved 22 August 2010 from

http://www.pwc.com/en_CA/ca/sustainability/publications/csr-trends-3-en.pdf

Corporate Watch. (2006). What's Wrong with Corporate Social Responsibility. Corporate Watch, Oxford, UK.

Davis, A. L. and Rothstein, H, R. (2006). The effects of the perceived behavioural integrity of managers on employee attitudes: A meta-analysis. Journal of Business Ethics, 67(4), 407419.

Dillon, P. W. and Fischer, K. (1992). Environmental management in corporations. Medford, MA: Tufts University Center for Environmental Management

Drexler, J. and Larson, E. (2000). Partnering: why project owner-contractor relationships change. Journal of Construction Engineering and Management, 126 (4), 293-7.

Doppelt, B. (2010), Leading Change toward Sustainability, 2nd ed., Greenleaf Publishing, Sheffield.

Dunphy, D., Griffiths, A. and Benn, S. (2003). Organizational change for corporate sustainability: a guide for leaders and change agents of the future, Routledge, Abingdon, UK.

EABIS. (2009). Sustainable Value. Cranfield University Available [http://www.investorvalue.org/docs/EabisProjectFinal.pdf]

Epstein, M. (2008). Making sustainability work: best practices in managing, measuring corporate social, environmental and economic impacts, Greenleaf Publishing, Sheffield, UK.

Esrock, S. and Leichty, G. (1998). Social responsibility and web pages: self presentation or agenda setting?. Public Relation Review, Vol. 24 (3). 305-319. 
Ferguson, D. (2009). Measuring Business Value and Sustainability Performance. Doughty Centre for Corporate Responsibility, Cranfield University, United Kingdom

Fieseler, C., Fleck, M. and Meckel, M. (2010). Corporate Social Responsibility in the Blogosphere. Journal of Business Ethics, 91(4), 599-614.

Freeman, R. (1984). Strategic management. A stakeholder approach. Pitman Publishing: Massachusetts

Freeman, R. E., Martin, K. and Parmar, B. (2007). Stakeholder capitalism. Journal of Business Ethics, 74(4). 303-314.

Frynas, J, G. (2009). Corporate social responsibility in the oil and gas sector. Journal of World Energy Law and Business, 2(3), 178-195.

Gitmand, L. and Fargo, B. (2009). ESG in the mainstream: The role of companies in Environmental, Social and Govermental Integration, BSR.

Gjølberg, M. (2009). Measuring the immeasurable? Constructing an index of CSR practices and CSR performance in 20 countries. Scandinavian Journal of Management 25(1), 10-22.

Grant, A. M. (2007). Relational job design and the motivation to make a pro-social difference. Academy of Management Review, 32(2). 393-417.

Greening, D. W. and Turban, D. B. (2000). Corporate Social Performance as a Competitive Advantage in Attracting a Quality Workforce. Business \& Society, 39(3). 254-280.

GRI. (2008) A snapshot of Sustainability Reporting in the construction and real estate sector. Global Reporting Initiative, Amsterdam, Netherlands 
Jones,T., Shan, Y. and Goodrum, P.M., (2010). An investigation of corporate approaches to sustainability in the US engineering and construction industry. Construction Management and Economics, 28(9), 971-983.

Hammond, S.A. and Slocum, J.W. Jr. (1996). The impact of prior firm financial performance on subsequent corporate reputation. Journal of Business Ethics, 15, 159-165.

Hartman, L.P., Rubin, R.S. and Dhanda, K.K. (2007) The communication of corporate social responsibility: United States and European Union multinational corporations. Journal of Business Ethics 74, 373-389

Jackson, S. (2010) Mind the Gap: Making Sense of Sustainability from a business managers perspective, The Doughty Centre for Corporate Responsibility, Cranfield University, United Kingdom.

Kalpana, S,C. (2009). Corporate Social Responsibility in Construction in UK and India. Working Paper Series, Sardar Patel Institute of Economics and Social Research.

KPMG. (2008). Count me in: The readers' take on sustainability reporting. KPMG/SustainAbility.

Kotler, P. and Lee, N. (2005). Corporate Social Responsibility: Doing the Most Good for Your Company and Your Cause, Wiley, New York, NY.

Lampe, M., Ellis, S. R. and Drummond, C. K. (1991). What companies are doing to meet environmental protection responsibilities: Balancing legal, ethical, and profit concerns. Proceedings of the International Association for Business and Society: 527-537 
Lawrence, A. T. and Morell, D. (1995). Leading-edge environmental management: Motivation, opportunity, resources, and processes. In D. Collins \& M. Starik (Eds.), Research in corporate social performance and policy: 99-126. Greenwich, CT: JAI Press

Luo, X. and Bhattacharya, C. B. (2006). Corporate social responsibility, customer satisfaction, and market value. Journal of Marketing, 70(4). 1-18.

Makower, J. (2009.) State of Green Business 2009. Available at www.greenbiz.com.

Menon, A. and Menon, A. (1997). Enviropreneurial marketing strategy: The emergence of corporate environmentalism as market strategy. Journal of Marketing, 61(1), 51-67.

Maon, F., Lindgreen, A., and Swaen, V. (2009). Designing and implementing corporate social responsibility: an integrative framework grounded in theory and practice. Journal of Business Ethics, 87, 71-89.

Maon, F., Lindgreen, A. and Swaen, V. (2010). Organizational stages and cultural phases: a critical review and a consolidative model of corporate social responsibility development. International Journal of Management Reviews, 12(1), 20-38.

Mercer. (2009) Shedding light on approaches returns and impacts, London Available: http://www.mercer.com/surveys/1363935

Milne, M.J. and Adler, R.W. (1999). Exploring the reliability of social and environmental disclosures content analysis. Accounting, Auditing and Accountability, 12 (2), 237-256

Mirvis, P., Googins, B. and Kinnicut, S. (2010). Vision, mission, values: Guideposts to sustainability. Organizational Dynamics, 39(4) 316-32.

Montiel, I. (2008). Corporate social responsibility and corporate sustainability: Separate pasts, common futures. Organization Environment, 21, 245-268 
Murray, M. and Dainty, A.R.J. (2009). Corporate social responsibility in the construction industry. Abingdon, UK: Taylor \& Francis.

Myers, D. (2005). A review of construction companies' attitudes to sustainability'. Construction Management and Economics, 23(8),781-785.

Neu, D., Wasame, H. and Pedwell, K. (1998), Managing public impressions: environmental disclosures in annual reports. Accounting, Organizations and Society, Vol. 23 (3) 265-89.

Orlitzky. M., Schmidt. F., and, Rynes. S.L. (2003). Corporate social and financial performance: A meta-analysis. Organization Studies 24(3). 403-441.

Paine, L. S. (2003). Value shift: Why companies must merge social and financial imperatives to achieve superior performance?. New York, NY: McGraw-Hill

Peloza, J, and Yachin,R. (2008). Valuing Business Sustainability: A Systematic Review, Research Network for Business Sustainability.

Perrini, F., Russo, A., Tencati., and Vurro, C. (2009). Going beyond a long-lasting debate: What is behind the relationship between corporate social and financial performance. Cranfield University, UK.

Petrovic-Lazarevic, S. (2004) Corporate social responsibility in building and construction industry, Working Paper 36/04.

Pleon. (2005). Accounting for Good: the Global Stakeholder Report 2005. The Second World-wide Survey on Stakeholder Attitudes to CSR Reporting. Bonn: Pleon Kohtes Klewes $\mathrm{GmbH}$.

Podnar, K. and Golob, U. (2007). CSR expectations: the focus of corporate marketing, Corporate Communications. An International Journal, 12(4).326-340. 
Porter, M. E. and Kramer, M. R. (2006). Strategy and society: The link between competitive advantage and corporate social responsibility. Harvard Business Review 84 (12), 78-92.

Prottas, D. J. (2008). Perceived behavioural integrity: Relationships with employee attitudes, well-being and absenteeism. Journal of Business Ethics, 81(2). 313-322.

Reich, R. (1998). The new meaning of corporate social responsibility. California Management Review, 40(2), 243-254.

Roberts, C.B. (1991). Environmental disclosures: a note on reporting practices in mainland Europe. Accounting, Auditing and Accountability, 4 (3), 62-71.

Smith, N. C. (2003). Corporate social responsibility: Whether or how? California Management Review, 45(4). 52-76.

Spitzeck, H. (2010). The Governance of Corporate Responsibility: A Doughty 'How' to Guide. Doughty Centre for Corporate Responsibility, Cranfield University, United Kingdom.

Sustainability and UNEP. (2000). Global reporters: An International Benchmark of Corporate Sustainability Reporting. Sustainability, London.

Sustainability and UNEP. (2002). Trust Us: The Global Reporters 2002 Survey. Sustainability, London.

Sustainability, UNEP and Standard and Poor's. (2004). Risk and Opportunity: Best Practice in Non Financial Reporting. Sustainability, London.

Székely, F. and Knirsch, M. (2005). Responsible leadership and corporate social responsibility: Metrics for sustainable performance. European Management Journal 23 (5), $628-647$. 
Unerman, J. (2000). Methodological issues: Reflections on quantification in corporate social reporting content analysis. Accounting Auditing and Accountability Journal, 13 (5), 667-680.

Valentine, S., \& Barnett, T. (2003). Ethics code awareness, perceived ethical values and organizational commitment. Journal of Personal Selling \& Sales Management, 23(4): 359367.

Vredenburg, H., and Westley, F. (1993). Environmental leadership in three contexts: Managing for global competitiveness. Proceedings of the International Association of Business and Society, 495-500.

Winn, M. (1995). Corporate leadership and policies for the natural environment. In D. Collins \& M. Starik (Eds.), Research in corporate social performance and policy, supplement 1: 127161. Greenwich, CT: JAI Press

Willetts, R., Burdon, J., Glass, J., and Frost, M. (2010). Environmental and Sustainability Impact Assessment of Infrastructure in the United Kingdom. Transportation Research Record: Journal of the Transportation Research Board.2158. 143-150

Wilkinson, S. (2004). Conceptual Understanding of Corporate Social Responsibility in the UK Construction and Property Sectors, CIB 2004, Toronto.

WWF (World Wildlife Fund). (2004). Building Towards Sustainability: Performance and Progress among UK's Leading Housebuilders. WWF and Insight Investment, London.

Yu, T.W., Shen, Q., Kelly,J and Hunter, K. (2006). Investigation of critical success factors in construction project briefing by way of content analysis. Journal of Construction Engineering and Management, 132 (11), 1178-86. 
Zollo, M. (2008). Understanding and responding to societal demands on corporate responsibility (RESPONSE): Final Report, INSEAD, Copenhagen Business School, Bocconi, impact and the Leon Kozminski Academy of Entrepreneurship and Management. 
Table 1 - CSR organisation development stages (Maon et al, 2010)

\begin{tabular}{|c|c|c|}
\hline CSR cultural phase & Stage of CSR development & $\begin{array}{l}\text { CSR view and prominence } \\
\text { in organisational culture }\end{array}$ \\
\hline $\begin{array}{l}\text { CSR CULTURAL } \\
\text { RELECUTANCE }\end{array}$ & 1.Dismissing & $\begin{array}{l}\text { 'Winning at any cost } \\
\text { perspective'/ None }\end{array}$ \\
\hline \multirow[t]{3}{*}{ CSR CULTURAL GRASP } & 2.Self-protecting & $\begin{array}{l}\text { 'Reputation \& Philanthropy } \\
\text { perspective'/ CSR as } \\
\text { marginal }\end{array}$ \\
\hline & 3.Compliance seeking & $\begin{array}{l}\text { 'Requirements perspective'/ } \\
\text { CSR as worthy interest }\end{array}$ \\
\hline & 4.Capability seeking & $\begin{array}{l}\text { 'Stakeholder management } \\
\text { perspective'/ CSR as } \\
\text { influential }\end{array}$ \\
\hline \multirow[t]{3}{*}{$\begin{array}{l}\text { CSR CULTURAL } \\
\text { EMBEDMENT }\end{array}$} & 5. Caring & $\begin{array}{l}\text { 'Stakeholder dialogue } \\
\text { perspective'/ CSR as } \\
\text { embodied }\end{array}$ \\
\hline & 6. Strategizing & $\begin{array}{l}\text { 'Sustainability perspective'/ } \\
\text { CSR as prevailing }\end{array}$ \\
\hline & 7. Transforming & $\begin{array}{l}\text { 'Change the game } \\
\text { perspective'/ CSR as } \\
\text { ingrained }\end{array}$ \\
\hline
\end{tabular}

